An-Nadwah, Vol. XXVI, No.1, Januari-Juni 2020

\title{
Komunikasi Profetik Strategi Membangun Karakter Manusia \\ Perspektif Al Quran
}

\section{Oleh : IMAM EL ISLAMY}

\begin{abstract}
Abstrak: Pemberdayaan manusia merupakan suatu titik penting dalam kemajuan suatu bangsa, strategi dan berbagai cara dilakukan agar tercapai keinginan luhur pendiri Indonesia ini. Komunikasi profetik menjadi salah satu strategi pembangunan karakter manausia, sebab kemajuan bangsa dimulai dari kemajuan karakter manusianya. Komunikasi ini dikenal dengan komunikasi kenabian, dimana setiap pengambilan keputusan, sikap dan perilaku mengikut kepada nabi Muhammad. Maka dari itu komunikasi ini disebut Profetik. Metode penelitian yang digunakan adalah deskriptif explanatif dengan melihat fenomena sosial dilapangan lalu mengaitkan dengan literatur yang ada.
\end{abstract}

Kata Kunci : Komunikasi Profetik, Karakter, Qur'an.

\section{Pendahuluan}

Pemberdayaan sumber daya manusia menjadi penting dan perlu mendapat perhatian sebab pada kenyataannya pertumbuhan ekonomi yang tinggi tidak selalu dapat memecahkan persoalan kesejahteraan masyarakat. Peningkatan kualitas sumber daya manusia sangat penting dalam strategi kebijakan suatu wilayah karena manusia pada dasarnya merupakan sumber daya utama dalam pembangunan. Untuk itu pentingnya penekanan terhadap kualitas pembangunan manusia telah menjadi kebutuhan karena dengan sumber daya yang andal maka akan mendorong tercapainya kemajuan di segala aspek kehidupan. Sehingga, kualitas manusia memiliki andil besar dalam menentukan keberhasilan pembangunan wilayahnya. diupayakan untuk mampu meningkatkan pembangunan sumber daya manusia diantaranya dengan peningkatan akses terhadap pelayanan kebutuhan dasar seperti pendidikan, kesehatan, dan akses terhadap kebutuhan ekonomi. Pemerintah mempunyai kewajiban untuk 
menyediakan barang publik kepada masyarakat. Dalam penyediaan barang publik haruslah memperhatikan keadilan agar tercapai kesejahteraan yang merata. Terwujudnya pemerataan pembangunan merupakan cita-cita setiap daerah termasuk kabupaten Labuhanbatu, maka dari itu perlunya strategi kebijakan yang tepat demi tercapainya tujuan yang diharapkan

Namun potensi yang dimiliki ini seakan terbiarkan begitu saja tanpa bisa kita kelola dengan sebaik-baiknya. Ini dikarenakan karakter sumber daya manusia Indonesia masih terkekang menjadi konsumen dan pekerja bukan sebagai produsen. padahal untuk menjadi sebuah negara yang maju, pola fikir sumber daya manusia Indonesia harus dirubah, agar kebiasaan, sikap dan karakteristik juga berubah. ${ }^{1}$ Allah menciptakan manusia dengan segala kekurangan serta kelebihannya masing-masing, tidak ada manusia yang tidak memliki kemampuan. Seluruhnya memiliki kemampuan masing-masing ada yang unggul dalam bidang pendidikan, olahraga, agama, sosial dan sebagainya. ${ }^{2}$ Semua kelebihan yang ada didalam diri manusia ini tidak dimanfaatkan secara maksimal. Sebab karakter manusia yang sudah terbentuk bahwa saya tidak bisa menjadi apa-apa, bahwa saya hanya bisa seperti ini saja. Karakter apa adanya seperti ini tidak mencirikan ummat Islam yang pantang menyerah. Seperti yang terdapat didalam Alquran Surah At-Taubah ayat 105.

105. Dan Katakanlah: "Bekerjalah kamu, maka Allah dan Rasul-Nya serta orangorang mukmin akan melihat pekerjaanmu itu, dan kamu akan dikembalikan kepada (Allah) Yang Mengetahui akan yang ghaib dan yang nyata, lalu diberitakan-Nya kepada kamu apa yang telah kamu kerjakan.

Salah satu unsur yang tidak pernah lepas dari kehidupan manusia untuk memahami dan dipahami oleh orang lain adalah komunikasi. Dengan berkomunikasi manusia dapat menyampaikan pesan yang dirasakan, dilihat dan didengar dari orang

\footnotetext{
${ }^{1}$ Panji Anaraga, Psikologi Kerja, ( Jakarta : Rineka Cipta, 2001 ), hal. 29

${ }^{2}$ Muchlas samani, hariyanto, pendidikan karakter: konsep dan model, (Bandung: PT Remaja rosdakasrya, 2013 ), hal. 6
} 
lain. Oleh sebab itu menurut Dr. Evveret Kleinjam yang dikutip oleh Hafied Cangara dalam bukunya Pengantar Ilmu Komunikasi mengemukakakan bahwa : komunikasi merupakan bagian kekal dari kehidupan manusia seperti halnya bernafas, sepanjang manusia ingin hidup maka ia perlu berkomunikasi. ${ }^{3}$

Komunikasi profetik sebagai salah satu kajian dari ilmu komunikasi akan menemukan titik terang dan benang merah peran dan kontribusi komunikasi kenabian dalam sejarah perkembangan ilmu komunikasi. Komunikasi profetik tidak hanya dapat dipetakan dalam kelompok kerja agama saja tetapi dapat dipetakan dalam kelompok kerja ilmu secara umum sebab memuat urusan kemanusiaan dan agama secara bersamaan. Komunikasi profetik lebih bertendensi menjadi kerangka normative dibanding konsep empirik, namun praktis dan pragmatis untuk menampung dan memberi tempat bagi seluruh apresiasi keilmuan dalam khazanah Islam yang terkait dengan persoalan komunikasi. Komunikasi profetik bukan hanya persoalan dakwah tetapi juga persoalan kemanusiaan secara luas didalamnya terkandung usaha komunikasi yang berorientasi pada humanisasi, liberasi dan transendensi.

Tujuan kita berkomunikasi adalah untuk mengkonstruksi, memelihara, memperbaiki dan menstransformasi realitas. Karena model komunikasi tidak dapat merepresentasikan komunikasi itu sendiri, tetapi membimbing dan berkonsentrasi pada interaksi manusia, massa dan pribadi. Karena itu mempelajari komunikasi termasuk didalamnya mempelajari konstruksi, pengertian dan penggunaan modelmodel komunikasi itu sendiri. Sehingga dengan mengelaborasikan antara perencanaan komunikasi dengan nilai profetik maka akan

\section{A. Membangun Softskill Dalam Islam}

Manusia dianugerahi kemampuan untuk berpikir, kemampuan untuk memilah dan memilih mana yang baik dan mana yang buruk. Dengan kelebihan itulah manusia seharusnya mampu mengelola lingkungan dengan baik. Tidak hanya lingkungan yang perlu dikelola dengan baik, kehidupan sosial manusiapun perlu dikelola dengan baik.

\footnotetext{
${ }^{3}$ Hafied Cangara, Pengantar Ilmu Komunikasi, (Jakarta: Raja Grapindo Persada,2009), h. 1
} 
Sebab setiap manusia memiliki kelebihannya masing-masing tinggal bagaimana memanfaatkan nya serta mengaplikasikannya dalam pekerjaan.

Islam menempatkan kerja sebagai parameter peringkat kualitas manusia. Hal ini merupakan konsekuensi dari takwa sebagai proses kerja. Pada sisi lain Islam juga telah mengangkat kerja pada level kewajiban religious dengan menyebut kerja itu secara konsisten sebanyak 50 kali yang digandengkan dengan iman, alladzina amanu wa amilu al-shalihat. Karena eratnya kaitan antara iman dan amal itulah maka Rasulullah menyebut bahwa tidak bernilai iman yang tidak di implementasikan dalam kerja dan kerja yang tidak didasarkan pada Iman. ${ }^{4}$

"Tidak bernilai iman tanpa amal dan tidak bernilai amal yang tidak didasarkan pada iman." ( HR. Al-Thabrani )

Kerja adalah sebuah aktivitas yang menggunakan daya yang dianugerahkan Allah Swt. Manusia, secara garis besar, dianugerahi empat daya pokok. Pertama, daya fisik yang menghasilkan kegiatan fisik dan keterampilan. Kedua, daya pikir yang mendorong pemiliknya berpikir dan menghasilkan ilmu pengetahuan. Ketiga, daya kalbu yang menjadikan manusia mampu berkhayal, mengekspresikan keindahan, beriman, dan merasa, serta berhubungan dengan Allah, sang pencipta. Dan Keempat, daya hidup yang menghasilkan semangat juang, kemampuan menghadapi, tantangan dan mengulangi kesulitan. ${ }^{5}$

Penggunaan salah satu dari daya tersebut, betapapun sederhananya, dapat melahirkan kerja, atau amal dalam istilah Al-Qur'an. ${ }^{6}$ Kita tidak dapat hidup tanpa menggunakan paling sedikit salah satu dari daya-daya itu. Untuk melangkah kita memerlukan fisik, paling tidak guna menghadapi gaya tarik bumi. Oleh karena itu

\footnotetext{
${ }^{4}$ Syahrin Harahap, Jalan Islam Menuju Islam Paripurna, ( Jakarta : PT. Kharisma Putra Utama, 2016 ) hal. 206

${ }^{5}$ Quraish Shihab, Secercah Cahaya Ilahi hidup bersama Al-Qur'an, ( Bandung : PT. Mizan Pustaka, 2007 ) hal. 305

${ }^{6}$ Ismail Ragi al-Faruqi, Tawhid: its Implications for Thought and life, ( Pensylvania-USA : The International Institute of Islamic Thought, 1982 ) hal. 87
} 
kerja adalah keniscayaan. Akan tetapi perlu diingat bahwa kerja atau amal yang dituntuk Allah bukan hanya sekedar asal kerja, tetapi kerja yang Shalih. ${ }^{7}$

Etika Islam tulis Al Faruqi dalam bukunya menentang segala bentuk mintaminta, menentang tindakan dan cara hidup parasite yang makan keringat orang lain. Sunnah Rasulullah memaparkan kepada kita bahwasanya kerja-kerja ekonomi sangatlah dihargai, sedangkan pengangguran ekonomi sangatlah buruk. ${ }^{8}$ Maka mengaplikasikan skil yang kita miliki dalam pekerjaan akan menghasilkan hal yang maksimal.

\section{B. Membangun Karakter Manusia}

Dalam ajaran Islam setiap manusia merniliki kedudukan yang tinggi di sisi Allah Swt. apabila manusia tersebut benakwa kepada-Nya. Manusia bermartabat di sisi Allah Swt bukan karena kecerdasannya, kekayaannya, kepangkatannya dan lainlainnya, melainkan ketakwaan kepada Allah Swt itulah yang paling utama. Sama halnya dengan ummat Islam, mereka yang baik di sisi Allah Swt adalah yang senantiasa bertakwa kepada Allah Swt. Meskipun dalam kenyataannya masih ada muslim yang ketakwaannya kepada Allah Swt belum bisa dipenuhi, tetapi di sisi lain tidak kalah pentingnya ada juga muslim yang benar-benar takwa kepada Allah Swt dilunjukkan secara benar dan sungguh-sungguh dan ini merupakan bagian dari karakteristik Ummat Islam. ${ }^{9}$

Tujuan dari pendidikan karakter menurut Islam yang tidak lain adalah untuk menjadikan manusia yang berakhlak mulia. Dalam hal ini yang menjadi tolok ukur adalah akhlak Nabi Muhammad SAW dan yang menjadi dasar pembentukan karakter adalah al-Quran. Tetapi kita kita harus menyadari tidak ada manusia yang menyamai akhlaknya dengan Nabi Muhammad SAW.

Al-Quran adalah petunjuk bagi umat Islam. Seperti yang telah disinggung di atas bila kita hendak mengarahkan pendidikan kita dan menumbuhkan karakter yang

\footnotetext{
${ }^{7}$ Shalih Berarti “ yang sesuai, bermanfaat lagi memenuhi syarat-syarat dan nilai-nilainya.

${ }^{8}$ Syahrin Harahap, Jalan Islam Menuju Islam Paripurna .... hal. 210

${ }^{9}$ Arifin, M. Ilmu Pendidikan Islam. ( Jakarta: Bumi Aksara, 1994 ). Hal. 15
} 
kuat pada anak didik, kita harus mencontoh karakter Nabi Muhammad SAW yang memiliki karakter yang sempurna.

Firman Allah SWT dalam Qur'an surah Al Qalam ayat 4 :

4. Dan sesungguhnya kamu benar-benar berbudi pekerti yang agung.

Dalam pendidikan karakter yang berorientasi pada akhlak mulia kita wajib untuk berbuat baik dan saling membantu serta dilatih untuk selalu sabar, menahan amarah dan memaafkan kesalahan orang lain sebagaimana firman Allah SWT dalam Al-Qur'an Surah Ali Imran ayat 134 :

134. (yaitu) orang-orang yang menafkahkan (hartanya), baik di waktu lapang maupun sempit, dan orang-orang yang menahan amarahnya dan memaafkan (kesalahan) orang. Allah menyukai orang-orang yang berbuat kebajikan.

Dari uraian di atas maka tujuan pendidikan karakter menurut Islam adalah membentuk pribadi yang berakhlak mulia, karena Akhlak mulia adalah pangkal kebaikan. Orang yang berakhlak mulia akan segera melakukankebaikan dan meninggalkan keburukan ${ }^{10}$

Al-Maraghi dalam Tafsirnya menegaskan bahwa Allah SWT telah menjadikan dalam tiap diri pribadi umat manusia berupa fitrah keislaman yang disebut gharizah imaniy (naluri keimanan) dan melekat didalam hati senubari mereka. Sehingga, potensi beriman kepada Allah telah terlebih dahulu tertanam dalam diri manusia dan baik buruknya pribadi manusia tersebut tergantung upaya untuk mengembangkan potensi ketuhanan itu. ${ }^{11}$

Jika pendidikan karakter jauh dari akidah Islam, lepas dari ajaran religius dan tidak berhubungan dengan Allah, maka tidak diragukan lagi bahwa sesorang manusia akan memiliki sifat kefasikan, penyimpangan, kesesatan, dan kekafiran. Bahkan ia akan mengikuti nafsu dan bisikan-bisikan setan, sesuai dengan tabiat, fisik, keinginan dan tuntutannya yang rendah.

10 Abdulloh Muni, Pendidikan karakter, (Yogjakarta: PT Pustaka Insan Madan, Anggota IKAPI, 2010), Cet. 1, hal. 2

${ }^{11}$ Muhammad Mustafa al-Maraghi, tth:103 
Dari sini, jelaslah bahwa yang menjadi fundamen utama yang harus terbina dalam lingkungan keluarga adalah prinsip tauhid. Hal ini dianggap sebagai prasyarat utama dalam pendidikan karakter bagi anak oleh orang tuanya sebagai identitas keimanan yang harus ditanamkan sejak dini.

\section{Konsep Shalat Lima Waktu Sebagai Pembentuk Karakter ${ }^{12}$}

\section{Perintah Untuk Mentaati Sesuatu Yang Ia Lebih Berkuasa Daripada}

\section{Kita (Pimpinan Tertinggi Atau Pemerintahan Negara)}

Kaitannya dengan sholat adalah sholat merupakan bentuk ketaatan hamba dengan Rabb-nya. Sedangkan contoh real dalam kehidupan sehari-hari adalah rakyat wajib mentaati penguasanya. Seperti firman Allah memerintahkan kita untuk patuh terhadap penguasa ( Ulil amri ) yang terdapat didalam Al-Qur'an surah An-Nisa ayat 59

\section{Perintah Untuk Tepat Dalam Ucapan Dan Perbuatan}

Kaitannya dengan sholat, dalam sholat setiap bacaan wajib ditempatkan pada waktu yang tepat. Semisal, bacaan ruku' harus ia baca saat ruku', bacaan sujud harus ia baca saat sujud. Tidak boleh dibolak-balik.

Sedangkan contoh nyata dalam kehidupan sehari-hari adalah ketika kita bergaul dengan orang lain hendaknya kita memperhatikan karakteristik orang tersebut. Karena tidak setiap orang bisa kita perlakukan dengan sikap yang sama.

\section{Hendaknya Melakukan Sesuatu Secara Berurutan Mulai Dari Yang}

\section{Paling Utama}

Kaitannya dengan shalat, shalat adalah ibadah yang awalnya dimulai dengan takbir. Karena takbir adalah sesuatu yang utama. Bahkan wajib bertakbir sebelum memulai shalat.

Begitu juga dalam kehidupan sehari-hari, ketika kita memiliki banyak rencana maka pilihlah yang paling utama atau paling manfaat atau yang paling wajib terlebih dahulu untuk kita kerjakan dan teratur. Seperti yang terdapat didalam al-qur'an surah As-shaff ayat 4.

${ }^{12}$ Misa Abdu, Al-Khusyu' fish Shalah wa Asraruhu, (terj.) Jujuk Najibah Ardianingsih, Menjernihkan Batin dengan Shalat Khusyu', (Yogyakarta: Mitra Pustaka, 2005), cet. 3, Hal. 13-17 


\section{Perintah Untuk Disiplin Dalam Mengatur Waktu}

Kaitannya dengan shalat, shalat adalah ibadah yang telah ditentukan waktunya. Seorang muslim tidak boleh mengawalkan ataupun mengakhirkan pelaksanaannya ataupun menjamaknya terkecuali karena sebab tertentu. Karena asalnya, shalat ditunaikan tepat pada waktunya.

Dalam kehidupan sehari-hari, waktu merupakan sesuatu yang harus dijaga oleh seorang muslim. Ia harus digunakan dalam hal-hal yang mendatangkan manfaat baik itu dunia maupun akhirat. Ketika seorang muslim telah merencanakan sesuatu maka berusahalah untuk disiplin dalam pelaksanaannya.

\section{Anjuran Untuk Belajar Tentang Dasar Suatu Ilmu Agar Tingkatan-}

\section{Tingkatan Ilmu Diatasnya Tidak Rusak.}

Kaitannya dengan shalat adalah shalat merupakan amalan mendasar yang akan pertama kali dihisab oleh Allah. Jika shalatnya buruk maka amalan yang lainnya menjadi buruk pula. Jika shalatnya baik maka amalan yang lainnya menjadi baik.

Kaitannya dalam kehidupan sehari-hari atau contoh realnya, sebagai thalabul 'ilmi (pencari ilmu) jika ingin meraih keberhasilan dalam sebuah studi dan menguatkan pemahaman terhadap suatu ilmu hendaknya memulai belajar dari pelajaran yang paling mendasar terlebih dahulu sebelum mempelajari pelajaran yang diatasnya.

\section{Sikap Saling Menyayangi Terhadap Sesama Teman.}

Saling bertemu dan berkumpul bersama dalam suatu kegiatan keagamaan dapat menumbuhkan sikap untuk saling menyayangi terhadap teman yang lain. Berjabat tangan dapat mempersatukan hubungan silaturahmi, mengenal teman yang selama ini belum kita kenal sebelumnya, menunjukkan bahwa islam mengajarkan untuk bersikap ramah terhadap orang lain. ${ }^{13}$

\section{Meningkatkan Kecerdasan Emosi dan spiritual (ESQ)}

Kecerdasan emosi adalah kemampuan merasakan, memahami, dan secara efektif menerapkan daya dan kepekaan emosi sebagai sumber energi, informasi,

${ }^{13}$ Thalib, M. 40 Tanggung Jawab Orang Tua Terhadap Anak, ( Bandung : Pustaka AlKautsar : 1992 ) hal. 6 
koneksi, dan pengaruh manusia. Emosi adalah bahan bakar bagi otak agar mampu melakukan penalaran yang tinggi. Emosi menyulut kreatifitas, kolaborasi, inisiatif, dan transformasi; sedangkan penalaran logis berfungsi mengatasi dorongan-dorongan yang keliru dan menyelaraskan dengan proses, dan teknologi dengan sentuhan manusiawi.

\section{Konsep Kerja Lebah}

68. Dan Tuhanmu mewahyukan kepada lebah: "Buatlah sarang-sarang di bukitbukit, di pohon-pohon kayu, dan di tempat-tempat yang dibikin manusia"

69. kemudian makanlah dari tiap-tiap (macam) buah-buahan dan tempuhlah jalan Tuhanmu yang telah dimudahkan (bagimu). Dari perut lebah itu ke luar minuman (madu) yang bermacam-macam warnanya, didalamnya terdapat obat yang menyembuhkan bagi manusia. Sesungguhnya pada yang demikian itu benar-benar terdapat tanda (kebesaran Tuhan) bagi orang-orang yang memikirkan.

Lebah adalah serangga mungil yang tidak berakal. Ia tidak mampu berfikir, akan tetapi mereka mampu menyelesaikan sejumlah pekerjaan besar dengan sangat mengagumkan. Setiap pekerjaan tersebut membutuhkan perhitungan dan perencanaan khusus. Sangat luar biasa bahwa kecerdasan dan keahlian yang demikian ini ada pada setiap ekor lebah. Yang lebih mengagumkan adalah ribuan lebah bekerja sama secara teratur dan terencana dalam rangka mencapai satu tujuan yang sama, dan mereka melaksanakan bagian pekerjaan masing-masing secara penuh dan sungguh-sungguh tanpa kesalahan sedikitpun, inilah yang diadopsi oleh Nurcholis Madjid menyebut konsep lebah dengan kata itqan. ${ }^{14}$

Dalam menjalankan Peranannya, tidaklah mungkin lebah itu sendiri yang melakukan perhitungan berdasarkan kecerdasannya sendiri. Ini adalah bukti nyata bahwa setiap fase dalam hidupnya lebah tunduk pada hikmah dan kekuasaan

${ }^{14}$ Nurcholish Madjid, Kehampaan Spritual Masyarakat Modern Respond an Transformasi Nilai-Nilai Islam menuju Masyarakat Madani, ( Jakarta : Mediacita, 2004 ) hal. 470 
penciptanya. Lebah menjalani setiap tugas dan peranannya dengan ilham yang diberikan Allah, pencipta yang Maha perkasa.

Makhluk-makhluk mungil itu hanya menjalankan tugas berdasarkan Ilham yang mereka terima. Bahwa ketundukkan dan ketaatan pada peran yang menjadi tugasya, akan membuahkan hasil dan manfaat bagi koloni itu sendiri dan juga bagi makhluk lain. Konsep kerja lebah ini terdiri dari 6 sistem.

Pertama, Substansi Sebuah Sistem

Bahwa sebuah system terbangun melalui dua hal pokok, yaitu distribusi dan koordinasi atau diferensiasi dan integrasi. Dalam satu koloni lebah terdapat lebah pekerja, pejantan, dan ratu. Pemilihan ini menjadi isyarat bahwa sebuah system telah terbangun dalam koloni lebah. Ada pembagian tugas dan peran pada masing-masing jenis lebah itu, serta ada mekanisme koordinasi dalam menjalankan tugas dan peran masing-masing dalam rangka mencapai satu tujuan.

Spesialisasi dan distribusi kerja ini memberikan banyak pengaruh positif, diantaranya adalah penghematan waktu dan fokus pada satu jenis fungsi dan peran sehingga diperoleh hasil yang optimal. Spesialisasi mendorong lahirnya budaya Tabadul ( tukar-menukar), kerja sama saling membutuhkan serta amal jama'i ( kerja tim ). ${ }^{15}$ Bahwa tak satupun dari lebah pekerja itu yang bekerja secara individual, mereka bekerja dalam sebuah tim yang saling melengkapi, saling memahami, saling berkordinasi guna memaksimalkan dan mengefektifan kerja.

Kedua, Integrasi ( Takamul )

Integrasi atau koordinasi menjadi rukun kedua dari sebuah organisasi. Spesialisasi dan distribusi tidak banyak memberi arti bila tidak dilengkapi dengan integrasi dan koordinasi. Tidak adanya koordinasi akan berakibat hilangnya banyak potensi organisasi dengan sia-sia dan menjauhnya tujuan yang telah ditetapkan.

${ }^{15}$ Achyar Zein, Pesan-Pesan Moral dalam Al-Qur'an, ( Medan : Perdana Publishing, 2015 ) hal. 125 
Integrasi in dijumpai dalam koloni lebah yang memiliki karakteristik, tujuan yang satu, distribusi tugas dan peran, keahlian dan profesionalisme, kesamaan pemahaman dalam menghadapi situasi krisis dan darurat, dan kepemimpinan yang mengarahkan.

Ketiga, Fleksibel dan Elastis

Lingkungan sebuah organisasi itu bersifat dinamis. Ia selalu berubah karena itu tidak mungkin bagi suatu organisasi untuk tetap bertahan pada satu pola tertentu, tanpa mempertimbangkan dinamika lingkungannya. Maka fleksibilitas dan elastisitas dalam menghadapi dinamika lingkungan menjadi factor penting bagi keberhasilan atau kegagalan suatu system.

Koloni lebah tidak terikat oleh satu pola tertentu dalam menghadapi kondisi atau lingkungan yang berbeda. Mereka selalu beradaptasi dengan lingkungan sekitarnya sehingga mampu menjalankan tugas dan berproduksi secara berkesinambungan, koloni lebah mampu membuat sarangnya diatas bukit, dahan pohon, atap rumah, atau disarang-sarang yang telah disiapkan manusia.

Keempat, Pertumbuhan Strategis

Kehidupan suatu organsasi tidaklah berhenti dengan selesainya masa kerja para pengelolanya. Karena itu menjadi sangat strategis segala langkah dan upaya mempersiapkan kader yang akan melanjutkan masa depan organisasi. Yang sangat mengagumkan dari lebah adalah kemampuannya menjaga pertumbuhannya secara teratur dan seimbang.

Yaitu pertumbuhan yang menjamin kelangsungan komunitas lebah. Lebahlebah itu tidak hanya mampu menghasilkan lebah, lilin, atau serbuk sari, melainkan juga larva-larva yang memiliki spesialisasi sempurna dan memiliki kulifikasi sama.

Kelima, Otoritas dan Tanggung Jawab 
Otoritas ( Sulthah ) adalah hak untuk mengeluarkan perintah, komando, atau hak menetapkan sebuah kebijakan. Tanggung jawab ( Masuliyah) adalah komitmen untuk menunaikan suatu kewajiban. Hubungan oraganisasi dalam Islam didasari oleh dua prinsip ini, otoritas dan tanggung jawab.

Semua lebah memiliki tanggung jawab sekaligus otoritas yang memungkinkan baginya menjalankan tugas dengan sebaik mungkin. Lebah pekerja memiliki kebebasan dalam menjalankan perannya dan dalam rangka menciptakan kemaslahatan kerajaannya.

\section{Keenam, Hak dan Kewajiban}

Bahwa hubungan organisasi dalam Islam terikat oleh nilai-nilai moral yang disebut dengan hubungan antara hak dan kewajiban. Hak dan kewajiban mengikat semua pihak yang ada dalam organisasi, atasan dan bawahan. Pada dasarnya seseorang harus menjalankan kewajibannya terlebih dahulu sebelum menuntut haknya. Biasanya, konflik dan perpecahan itu muncul disebabkan oleh sikap menuntut hak tanpa memikirkan kewajiban atau menuntut hak yang lebih besar dari yang semestinya diterima. ${ }^{16}$

\section{Kesimpulan}

Setiap perintah Allah yang di berikan kepada umat islam tentunya memiliki faedah untuk kaum muslimin sendiri, seperti halnya umat islam di perintahkan untuk melaksanakan shalat, salah satu faedahnya yakni supaya umat islam selalu mengingat tuhannya dan senantiasa meminta karunianya dan manfaat yang lain yakni bisa mendapatkan ampunan dari Allah SWT.

Hal yang paling menonjol dari pembahasan diatas adalah, betapa banyaknya manfaat dari shalat selain beribadah kepada Allah yaitu mengajarkan kepada umat islam agar menghargai proses dari sebuah pekerjaan yang digambarkan dalam syarat dan rukun shalat, mengajarkan tentang kedisiplinan yang digambarkan dalam waktu-

16 Ahmad Djalaluddin, Manajemen Qur'ani menerjemahkan Idarah Ilahiyah dalam Kehidupan, ( Malang : UIN-Malang Press, 2007 ) hal. 77-81 
waktu shalat, kesehatan yang digambarkan dalam gerakat shalat, kebersamaan dan kekompakan yang dilakukan ketika shalat berjamaah dirumah maupun di masjid. Serta mengambil pelajaran dari lebah sebagai makhluk ciptaan Allah yang dapat berorganisasi dengan baik. Lebah memiliki 6 konsep yang dapat kita implementasikan yakni, Spesialisasi, Integrasi, Fleksibel dan Elastis, Pertumbuhan Strategis, Otoritas dan Tanggung Jawab, Hak dan Kewajiban.

Karakter dan pengembangan soft skill sangat berkaitan satu dengan lainnya, soft skill tidak akan berkembang bila karakter tidak diubah dan Allah memberi solusi kepada Ummat dengan sholat dapat membentuk karakter manusia menjadi lebih baik, tidak sampai disitu Allah juga menggambarkan lebah sebagai makhluk yang dapat dicontoh oleh Ummat dalam hal bekerja. Tentunya semua ini akan berhasil apabila kita mau bergerak merubah diri kita sendiri.

11. Bagi manusia ada malaikat-malaikat yang selalu mengikutinya bergiliran, di muka dan di belakangnya, mereka menjaganya atas perintah Allah. Sesungguhnya Allah tidak merubah keadaan sesuatu kaum sehingga mereka merubah keadaan yang ada pada diri mereka sendiri. Dan apabila Allah menghendaki keburukan terhadap sesuatu kaum, maka tak ada yang dapat menolaknya; dan sekali-kali tak ada pelindung bagi mereka selain Dia

Sehingga Indonesia dengan segala kelebihan yang dimiliki sudah cukup untuk menjadikannya sebagai negera maju, namun sumber daya manusia yang kita miliki masih suka berfikir terbelakan artinya hanya bekerja sebatas mencari makan, tidak ada peningkatan karakter serta kemampuan yang dialami oleh rakyat Indonesia sebab kebiasaan masyarakat dengan menerima apa adanya. Apabila kebiasaan ini dapat dirubah dengan sholat 5 waktu serta mencontoh lebah, penulis yakin negara akan mencapai cita-cita sebagai negeri yang Baldatun Thayyibatun wa Rabbul Ghafur. 
An-Nadwah, Vol. XXVI, No.1, Januari-Juni 2020

\section{Daftar Pustaka}

Al Quran dan Terjemah

Anaraga, Panji, 2001. Psikologi Kerja, Jakarta : Rineka Cipta.

Arifin, M. 1994. Ilmu Pendidikan Islam. Jakarta: Bumi Aksara.

Djalaluddin, Ahmad, 2007. Manajemen Qur'ani menerjemahkan Idarah Ilahiyah dalam Kehidupan, Malang: UIN-Malang Press.

Harahap, Syahrin, 2016. Jalan Islam Menuju Islam Paripurna, Jakarta : PT. Kharisma Putra Utama.

Madjid, Nurcholish, 2004. Kehampaan Spritual Masyarakat Modern Respond an Transformasi Nilai-Nilai Islam menuju Masyarakat Madani, Jakarta : Mediacita.

Misa Abdu, 2005. Al-Khusyu' fish Shalah wa Asraruhu, (terj.) Jujuk Najibah Ardianingsih, Menjernihkan Batin dengan Shalat Khusyu', Yogyakarta: Mitra Pustaka.

Muchlas samani, hariyanto, 2013. pendidikan karakter: konsep dan model, Bandung: PT Remaja rosdakasrya.

Muni, Abdulloh, 2010. Pendidikan karakter, Yogjakarta: PT Pustaka Insan Madan, Anggota IKAPI.

Ragi al-Faruqi, Ismail, 1982. Tawhid: its Implications for Thought and life, Pensylvania-USA : The International Institute of Islamic Thought.

Shihab, Quraish, 2007. Secercah Cahaya Ilahi hidup bersama Al-Qur'an, Bandung : PT. Mizan Pustaka.

Thalib, M. 1992. 40 Tanggung Jawab Orang Tua Terhadap Anak, Bandung : Pustaka Al-Kautsar.

Zein, Achyar, 2015. Pesan-Pesan Moral dalam Al-Qur'an, Medan : Perdana Publishing. 